Article

\title{
Gene Expression Profiling and Protein Analysis Reveal Suppression of the C-Myc Oncogene and Inhibition JAK/STAT and PI3K/AKT/mTOR Signaling by Thymoquinone in Acute Myeloid Leukemia Cells
}

\author{
Belal Almajali ${ }^{1}(\mathbb{D})$, Muhammad Farid Johan ${ }^{2} \mathbb{D}$, Abdullah Saleh Al-Wajeeh ${ }^{3} \mathbb{D}$, Wan Rohani Wan Taib ${ }^{1}$, \\ Imilia Ismail ${ }^{1}\left(\mathbb{D}\right.$, Maysa Alhawamdeh ${ }^{4}$, Nafe M. Al-Tawarah ${ }^{4}$, Wisam Nabeel Ibrahim ${ }^{5}$ (D), \\ Futoon Abedrabbu Al-Rawashde ${ }^{1}$ (D) and Hamid Ali Nagi Al-Jamal ${ }^{1, *(D)}$
}

1 School of Biomedicine, Faculty of Health Sciences, Universiti Sultan Zainal Abidin (UniSZA), Kuala Nerus 21300, Terengganu, Malaysia; bel_basss@yahoo.com (B.A.); wanrohani@unisza.edu.my (W.R.W.T.); imilia@unisza.edu.my (I.I.); futoonrawashdeh1001@gmail.com (F.A.A.-R.)

2 Department of Haematology, School of Medical Sciences, Universiti Sains Malaysia, Kubang Kerian 16150, Kelatan, Malaysia; faridjohan@usm.my

check for updates

Citation: Almajali, B.; Johan, M.F.; Al-Wajeeh, A.S.; Wan Taib, W.R.; Ismail, I.; Alhawamdeh, M.; Al-Tawarah, N.M.; Ibrahim, W.N.; Al-Rawashde, F.A.; Al-Jamal, H.A.N. Gene Expression Profiling and

Protein Analysis Reveal Suppression of the C-Myc Oncogene and Inhibition JAK/STAT and PI3K/AKT/mTOR Signaling by Thymoquinone in Acute Myeloid Leukemia Cells. Pharmaceuticals 2022, 15, 307. https://doi.org/10.3390/ ph15030307

Academic Editor: Olaf-Georg Issinger

Received: 25 January 2022 Accepted: 28 February 2022 Published: 3 March 2022

Publisher's Note: MDPI stays neutral with regard to jurisdictional claims in published maps and institutional affiliations.

Copyright: () 2022 by the authors Licensee MDPI, Basel, Switzerland. This article is an open access article distributed under the terms and conditions of the Creative Commons Attribution (CC BY) license (https:// creativecommons.org/licenses/by/ $4.0 /)$.
3 Anti-Doping Lab Qatar, Doha 27775, Qatar; asaleh@adlqatar.qa

4 Department of Medical Laboratory Sciences, Faculty of Sciences, Mutah University, Alkarak 61710, Jordan; maysa5005@yahoo.com (M.A.); nafitawa77@gmail.com (N.M.A.-T.)

5 Department of Biomedical Sciences, College of Health Sciences, QU Health, Qatar University, Doha 122104, Qatar; w.ibrahim@qu.edu.qa

* Correspondence: aljamalhamid@unisza.edu.my; Tel.: +60-174729012

\begin{abstract}
Overexpression of c-Myc plays an essential role in leukemogenesis and drug resistance, making c-Myc an attractive target for cancer therapy. However, targeting c-Myc directly is impossible, and c-Myc upstream regulator pathways could be targeted instead. This study investigated the effects of thymoquinone (TQ), a bioactive constituent in Nigella sativa, on the activation of upstream regulators of c-Myc: the JAK/STAT and PI3K/AKT/mTOR pathways in HL60 leukemia cells. Nextgeneration sequencing (NGS) was performed for gene expression profiling after TQ treatment. The expression of $c-M y c$ and genes involved in JAK/STAT and PI3K/AKT/mTOR were validated by quantitative reverse transcription PCR (RT-qPCR). In addition, Jess assay analysis was performed to determine TQ's effects on JAK/STAT and PI3K/AKT signaling and c-Myc protein expression. The results showed 114 significant differentially expressed genes after TQ treatment $(p<0.002)$. DAVID analysis revealed that most of these genes' effect was on apoptosis and proliferation. There was downregulation of $c-M y c$, PI3K, AKT, mTOR, JAK2, STAT3, STAT5a, and STAT5b. Protein analysis showed that TQ also inhibited JAK/STAT and PI3K/AKT signaling, resulting in inhibition of c-Myc protein expression. In conclusion, the findings suggest that TQ potentially inhibits proliferation and induces apoptosis in HL60 leukemia cells by downregulation of c-Myc expression through inhibition of the JAK/STAT and PI3K/AKT signaling pathways.
\end{abstract}

Keywords: thymoquinone; leukemia; c-Myc; JAK/STAT; PI3K/AKT; signaling; apoptosis

\section{Introduction}

Acute myeloid leukemia (AML) is the most common acute leukemia in adults [1]. AML is a hematological malignancy characterized by multiple acquired mutations that affect cell biological processes such as cell growth, proliferation, and apoptosis [2]. The $c-M y c$ oncogene is overexpressed in HL60 AML cells [3]. It mediates multiple tumor cell survival pathways in most human cancers and represents a promising therapeutic target in several cancers $[4,5]$. However, drugs cannot directly target c-Myc because it has no specific 
active site for small molecules. It is found mainly in the nucleus, and it is impossible to target the nuclear c-Myc by monoclonal antibodies [6]. Therefore, targeting the upstream signaling of c-Myc and the PI3K/AKT/mTOR and JAK/STAT pathways could indirectly inhibit c-Myc expression [7]. In mammals, the JAK/STAT and PI3K/AKT/mTOR pathways are the principal signaling mechanisms for many growth factors and cytokines, and the activation of these pathways stimulates cell proliferation, differentiation, cell migration, and apoptosis [8]. However, the JAK/STAT and PI3K/AKT/mTOR pathways are constitutively activated in many cancers, including leukemia, due to the fact of genetic events such as mutations in cytokine receptors and aberrant chromosomal translocations [9]. C-Myc was overexpressed by constitutive activation of the JAK/STAT and PI3k/AKT signaling pathways [10].

Advances in AML treatment have led to a better prognosis for younger patients, but the outcomes were poor for elderly patients, who make up the majority of new cases [11]. Therefore, there is an urgent need for a novel and more efficient treatment for such malignancies. Accumulated evidence based on in vivo and in vitro studies indicated the anti-cancer properties of compounds obtained from natural products [12]. Thymoquinone (TQ), chemically known as 2-methyl-5-isopropyl-1,4-benzoquinone, is an active phytochemical compound of Nigella sativa (black seeds) that has shown anti-proliferative, proapoptotic, and anti-metastatic properties on numerous cancer cell types including leukemia cells $[13,14]$. In the present study, to understand the effect of TQ on gene regulation in AML cells, gene expression profiling using next-generation sequencing (NGS) technology was performed to determine the changes in gene expression after TQ treatment. The Database for Annotation, Visualization, and Integrated Discovery (DAVID) online bioinformatics tool was used to evaluate the changes in mRNA expression in the HL60 leukemia cells after TQ treatment. NGS-based analyses have produced significant new understandings into the molecular pathogenesis of AML $[15,16]$. The expression of targeted genes involved in JAK/STAT and PI3K/AKT/mTOR was verified by RT-qPCR in TQ-treated HL60 cells compared to untreated cells. Moreover, the protein expression and their phosphorylation status in the JAK/STAT and PI3K/AKT/mTOR pathways and the c-Myc protein were studied using Jess simple Western analysis. Therefore, the current study improved the present knowledge of TQ effect mechanisms and provides a practical technique for future studies on pharmacogenomics.

\section{Materials and Methods}

\subsection{Cell Line and Growth Media}

The HL60 cell line was obtained from (Elabscience Biotech Co., Ltd., Wuhan, China) and cultured in a complete medium containing Roswell Park Memorial Institute (RPMI) 1640 Medium (Nacalai Tesque, Kyoto, Japan), fetal bovine serum (FBS) 10\% (Tico Europe, Holland), and $1 \%$ penicillin/streptomycin (Nacalai Tesque, Kyoto, Japan) in T-25 culture flasks at $37{ }^{\circ} \mathrm{C}$ with $5 \% \mathrm{CO}_{2}$ in a humid incubator [17]. The medium was changed every 3-4 days. The HL60 cells were passaged at 80-90\% confluence for the next experiments.

\subsection{TQ Treatment}

TQ was purchased from Sigma-Aldrich (Munich, Germany). Then, $5 \mathrm{mM}$ of TQ was prepared in dimethyl sulfoxide (DMSO) as a stock solution. Based on our published data, cells were treated with $2 \mu \mathrm{M}$ of TQ diluted in a complete RPMI culture medium as half-maximal inhibitory concentration $\left(\mathrm{IC}_{50}\right)$ and incubated for $48 \mathrm{~h} \mathrm{[14].}$

\subsection{RNA Extraction}

According to the manufacturer's protocol, total RNA from TQ-treated and untreated HL60 cells were extracted using the ReliaPrep ${ }^{\mathrm{TM}}$ RNA Cell Miniprep System (Promega, Madison, WI, USA). The concentration and purity of RNA were measured using a NanoPhotometer ${ }^{\circledR}$ NP80 (Implen GmbH, München, Germany). 


\subsection{Next-Generation Sequencing for mRNA Expression Profiling}

The gene expression profiles of mRNAs were conducted using the NGS analysis, Illumina platform, Agilent Technologies (Seoul, South Korea). The quality of sequencing raw data was inspected using FastQC (version 0.11.8). Low-quality reads (i.e., reads with a Phred score less than Q20), adapter, and poly G sequences were removed using Fastp [18]. The clean reads were inspected again using FastQC to make sure the unwanted reads were removed. The clean reads were then aligned against a human reference genome (version 38, downloaded from the Ensembl database) using Spliced Transcripts Alignment to a Reference (STAR) version 2.7.3a [19]. STAR is an aligner developed to manage the obstacles of RNA-seq data mapping using a method to account for spliced alignments. Prior to running the alignment, the reference genome index was built, and exon information was extracted from the latest version of the gene annotation file (version 35, downloaded from GENCODE) using STAR. Next, the aligned RNA-seq reads, in BAM format, were quantified using featureCounts (version 1.6) [20]. This gene-level quantification system uses a gene transfer format (GTF v35) file with gene models and counts the number of reads that align with each gene (i.e., read count).

In this study, DESeq2 [21] was adopted for differential gene expression (DEG) analysis. The tool takes featureCounts output (raw counts) as input. Many factors influence raw read counts such as transcript length and the total number of reads. Thus, to compare expression levels between samples, raw read normalization was performed. DESeq2 conducts internal normalization, where the geometric mean is calculated per gene across all samples. Prior to running the DEG analysis, sample-level and gene-level QC were performed on the count data. At the sample level QC, principal component analysis (PCA) was constructed to identify any potential outliers. At gene-level QC, genes that had zero or few mean read counts (less than 10) were omitted for downstream analysis. This increases the power to detect differentially expressed genes. Lastly, DESeq2 fits negative binomial generalized linear models for genes and utilizes the Wald test for significance testing. DEGs that passed the following filters were categorized as significant DEGs: $p$-adjusted value $(p$-adj $)<0.05$ and $\log$ fold change (lfc) $>1$ or $<-1$, which is equivalent to $>2$ - or $<-2$-fold change, respectively. All significantly affected genes were uploaded into the DAVID database to analyze functions and pathways associated with TQ treatment.

\subsection{DAVID Database Analysis}

The Database for Annotation, Visualization, and Integrated Discovery (DAVID) is a free powerful software that classifies functional genes (https://david.ncifcrf.gov/) (accessed on 5 October 2021) [22]. It combines biological processes, the Kyoto Encyclopedia of Genes and Genomes (KEGG) pathway, and Gene Ontology (GO). By using the software, genes affected after TQ treatment can be grouped to sets of related biological functions or signaling pathways by calculating the similarity of global annotation profiles with the agglomeration algorithm method. This study selected the expression analysis systematic explorer (EASE) score $=0.1$ as the default and specified pathways with a Bonferroni $p$-value of $<0.05$ as significant.

\subsection{Reverse Transcription Quantitative Polymerase Chain Reaction (RT-qPCR)}

cDNA was synthesized from RNA (100 ng) that was extracted from treated and untreated HL60 cells using the GoTaq 2-Step RT-qPCR System (Promega, USA) according to the manufacturer's protocol. The amplifications of PCR were performed using $50 \mu \mathrm{L}$ of GoTaq PCR Master Mix and $2 \mu \mathrm{L}$ of cDNA: a denaturing step at $95^{\circ} \mathrm{C}$ for 2 min followed by 40 cycles of denaturation at $96^{\circ} \mathrm{C}$ for $15 \mathrm{~s}$, then annealing and an extension step at $60^{\circ} \mathrm{C}$ for 1 min using a StepOne RT-qPCR System (Applied Biosystems, Waltham, MA, USA). StepOne Software v2.3 (Applied Biosystems) was used in data analysis. Beta-actin ( $\beta$-actin) was used as a housekeeping gene. The fold changes of gene expression levels were evaluated by relative quantification of targeted genes using the $2^{-\Delta \Delta \mathrm{Cq}}$ method [23]. The primer sequences are listed in Table 1. All experiments were performed in triplicate. 
Table 1. Sequences of primers used to quantify gene expression by RT-qPCR.

\begin{tabular}{|c|c|c|}
\hline Gene Name & Primer Sequence $\left(5^{\prime}\right.$ to $\left.3^{\prime}\right)$ & References \\
\hline \multirow{2}{*}{$J A K 2$} & F: TGTCTTACCTCTTTGCTCAGTGGCG & \multirow{2}{*}[24]{} \\
\hline & R: CAATGACATTTTCTCGCTCGACAGC & \\
\hline \multirow{2}{*}{ STAT3 } & F: GATTGACCAGCAGTATAGCCGCTTC & \multirow{2}{*}{ [25] } \\
\hline & R: CTGCAGTCTGTAGAAGGCGTG & \\
\hline \multirow{2}{*}{ STAT5a } & F: GTCCTGAAGACCCAGACCAA & \multirow{2}{*}{ [26] } \\
\hline & R: GTTGCGGGTGTTCTCATTTT & \\
\hline \multirow{2}{*}{ STAT5b } & F: CATTTTCCCATTGAGGTGCG & \multirow{2}{*}{ [27] } \\
\hline & R: GGGTGGCCTTAATGTTCTCC & \\
\hline \multirow{2}{*}{ PI3K } & F: TTAGCTATTCCCACGCAGGA & \multirow{2}{*}[28]{} \\
\hline & R: CACAATAGTGTCTGTGACTC & \\
\hline \multirow{2}{*}{$A K T$} & F: CTGAGATTGTGTCAGCCCTG & \multirow{2}{*}{ [29] } \\
\hline & R: CACAGCCCGAAGTCTGTGATCTTA & \\
\hline \multirow{2}{*}{ mTOR } & F: ATGCAGCTGTCCTGGTTCTC & \multirow{2}{*}[28]{} \\
\hline & R: AATCAGACAGGCACGAAG & \\
\hline \multirow{2}{*}{$c-M y c$} & F: CCACAGCAAACCTCCTCACA & \multirow{2}{*}[30]{} \\
\hline & R: TCCAACTTGACCCTCTTGGC & \\
\hline \multirow{2}{*}{$\beta$-actin } & F: CTGGCACCCAGGACAATG & \multirow{2}{*}{ [31] } \\
\hline & R: GCCGATCCACACGGAGTA & \\
\hline
\end{tabular}

\subsection{Protein Analysis Using Jess Simple Western Analysis}

Treated and untreated HL60 leukemia cells were harvested and washed with ice-cold PBS. The protein lysate was obtained by incubating the cells with RIPA buffer containing protease inhibitor cocktail (Nacalai Tesque, Kyoto, Japan) for $15 \mathrm{~min}$ on ice. Then, the lysate was centrifuged at $10,000 \times g$ for $10 \mathrm{~min}$ at $4{ }^{\circ} \mathrm{C}$. The BCA Protein Assay Kit (Heart, Xi'an, China) was used to measure the concentrations of the proteins in the supernatant. Capillary Western analyses were performed using the Jess simple Western analysis (Neoscience, Selangor, Malaysia) according to the manufacturer's protocol. Briefly, cell lysates were diluted with $0.1 \mathrm{X}$ sample buffer to a concentration of $1 \mathrm{mg} / \mathrm{mL}$ and then diluted with fluorescent $5 \mathrm{X}$ master mix at a $4: 1$ ratio and heated at $95{ }^{\circ} \mathrm{C}$ for $5 \mathrm{~min}$. In total, $3 \mu \mathrm{L}$ of each sample were loaded into the plate. A 12-230 kDa cartridge was used. The target proteins were immune-probed with primary antibodies that were diluted in antibody buffer at a 1:10 ratio (i.e., anti-JAK, anti-pJAK, and anti-c-Myc (Novus Biological, Littleton, CO, USA); anti-STAT3, anti-pSTAT3, anti-STAT5, anti-pSTAT5, anti-AKT, anti-pAKT, anti-PTEN, and anti-PI3K (R\&D Systems, Minneapolis, MN, USA); anti-pPI3K (Tyr458/Tyr199) (Invitrogen, Waltham, MA, USA)) followed by HRP-conjugated secondary antibodies. In total, $10 \mu \mathrm{L}$ of primary and secondary were loaded for each sample. The plate was spun down for $5 \mathrm{~min}$ at $1000 \times g$ to remove bubbles. Subsequently, capillaries and the plate were loaded into the Jess machine. Protein separation, blocking, antibody incubation, and signal detection were conducted automatically by the Jess system. The Compass software provided by the manufacturer was used in the data analysis. The normalization reagent detects proteins in capillaries by binding a biomolecule to an amine group and removing the housekeeping protein that can cause unreliable expression. The Jess technology did not need a control in the experiment.

\subsection{Statistical Analysis}

Kruskal-Wallis and Mann-Whitney tests were conducted for statistical analysis using GraphPad Prism 8.4.3 (San Diego, CA, USA), and $p<0.05$ was considered as significant. 


\section{Results}

\subsection{Thymoquinone Induced Differentially Expressed Genes in HL60 Cells}

The gene expression profiling of HL60 leukemia cells before and after TQ-treatment was performed for the whole transcriptome using NGS analysis. There were more than 1900 genes that showed different expression in TQ-treated HL60 leukemia cells. Volcano plots of the gene expression data in HL60 associated with TQ treatment (Figure 1) show significant DEGs at $p$-adj $<0.05$ and fold change with absolute value $>1$. There were 54 genes that showed significant upregulation, and 60 genes were significantly downregulated after treatment of HL60 cells with $2 \mu \mathrm{M}$ TQ. In general, tumor suppressor genes, including pro-apoptotic genes, were upregulated, while many oncogenes were downregulated. The gene expression profiling analysis also showed 100 obviously differentially expressed genes of down- versus upregulated genes in three TQ-treated HL60 cell samples compared to three untreated samples (Figure 2).

Free online DAVID Functional Annotation Bioinformatics Microarray Analysis was conducted to analyze possible mechanisms of the top modulated genes in HL60 cells related to TQ treatment. The biological process analysis (Figure 3) showed that the majority of genes were distributed in $\mathrm{G}$ protein-coupled receptor pathways (11 genes were involved), immune response (10 genes), regulation of GTPase activity (9 genes), inflammatory response (8 genes), cytokine-mediated and cell surface receptor pathways (7 genes each), regulation of angiogenesis and cell adhesion (6 genes each), and regulation of apoptosis (5 genes). In cellular components (Figure 4). The plasma membrane was the active site for the majority of affected genes (86 genes).

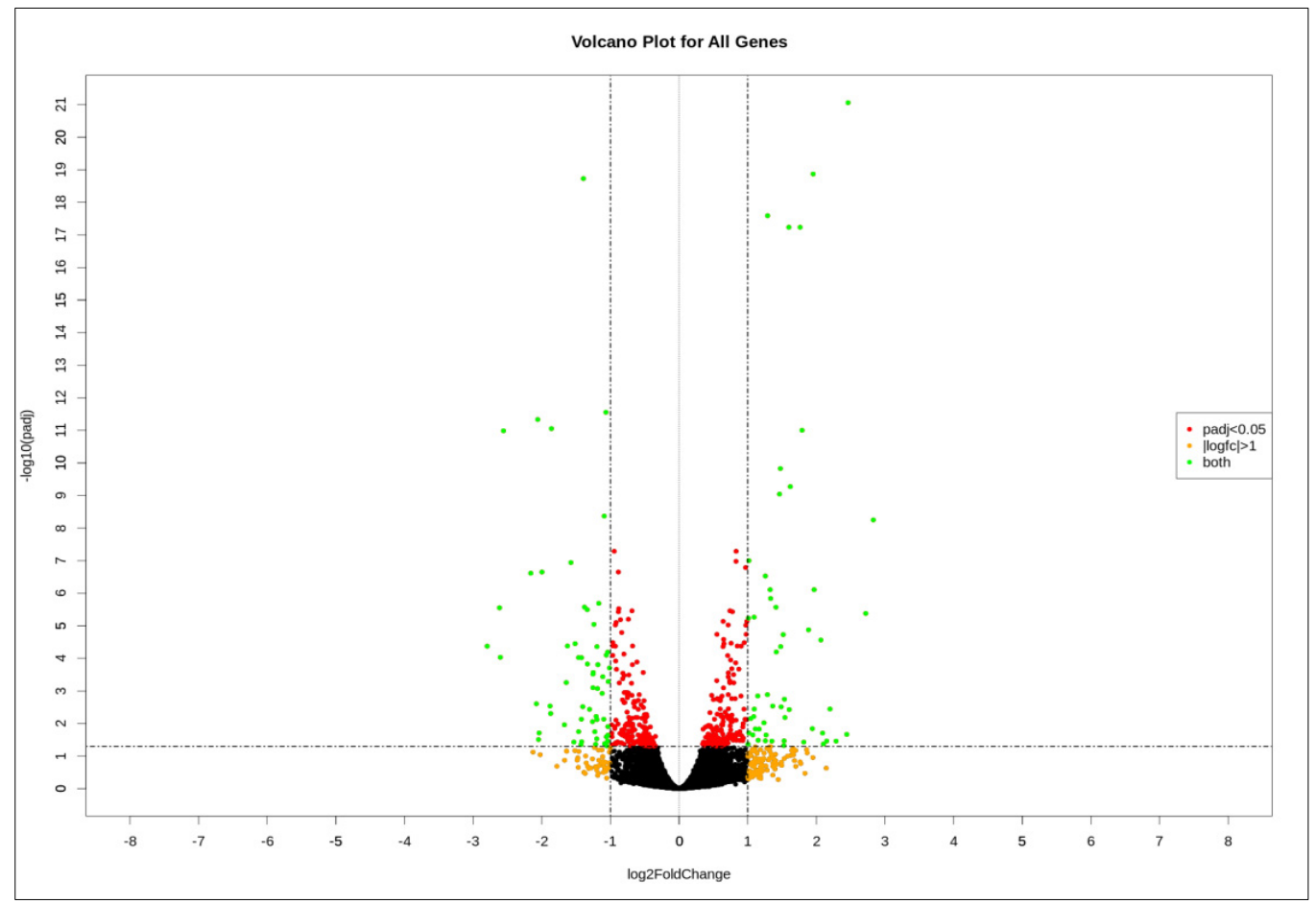

Figure 1. The volcano plot above shows the distribution of all the DEGs identified in this study. Each dot represents a single gene. Green dots are significant genes with $p$-adj $<0.01$ and $\mid \log 2$ fold change I $>1$ (equivalent to a fold change of magnitude greater than 2 ). 


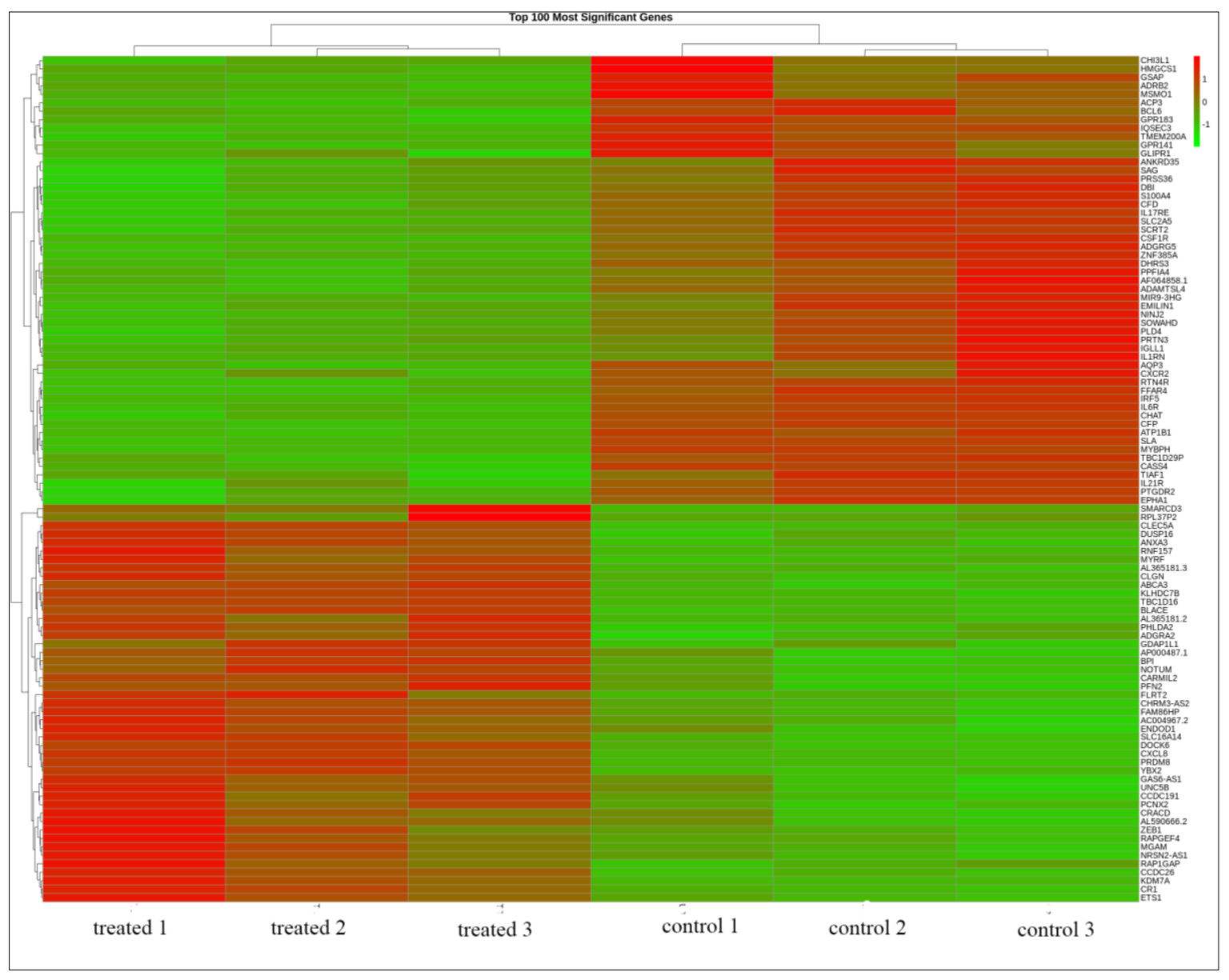

Figure 2. Heatmap of the top 100 significant DEGs in TQ-treated cell samples compared to control samples $(p-a d j<0.01)$. The red color indicates upregulation, and the green color indicates downregulation. Each row represents one gene.

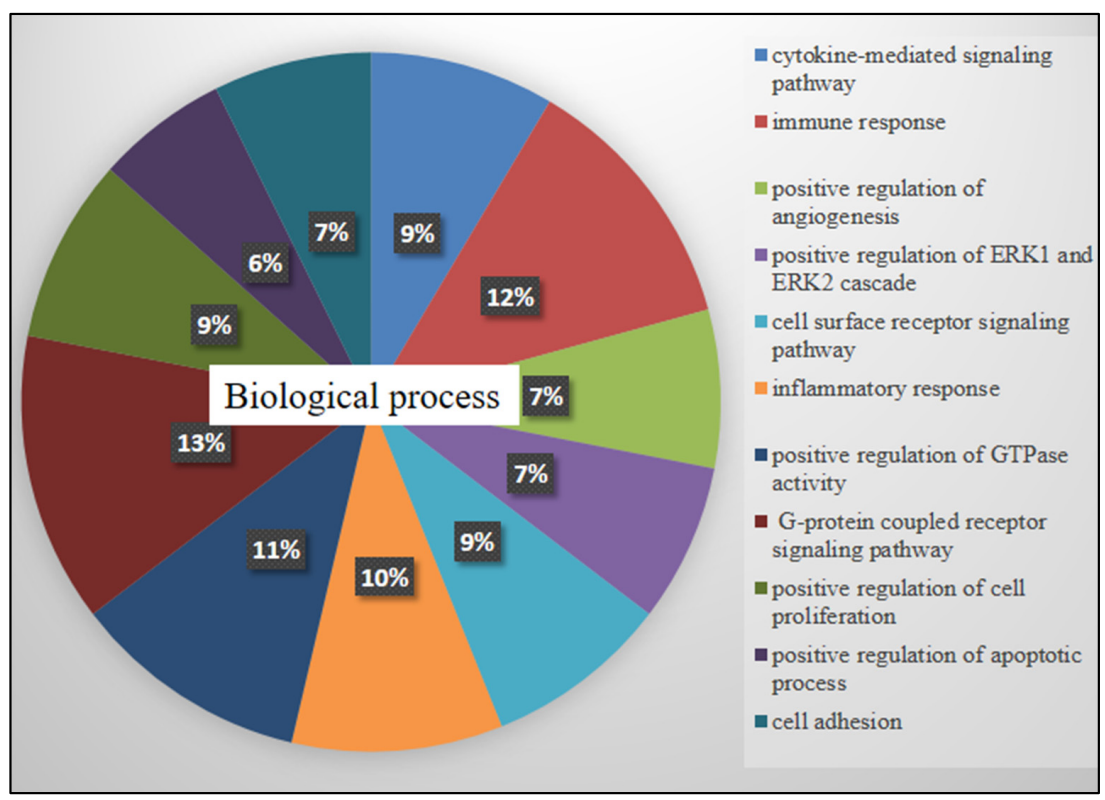

Figure 3. DAVID software analyzed the possible biological processes of the significantly affected genes in treated HL60 cells. Biological activation based on extracellular signals was highly affected after TQ treatment. The area of each category represents the percentages of involved genes to each other $(p<0.05)$. 


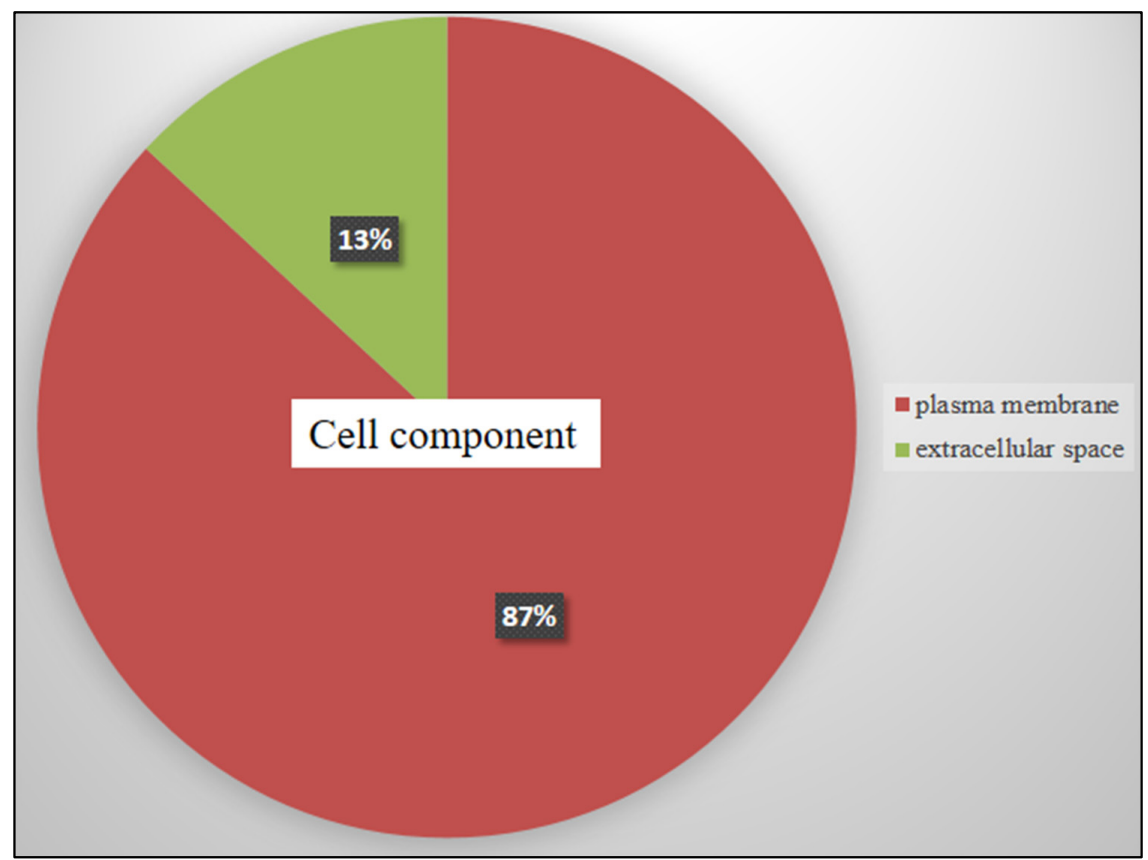

Figure 4. DAVID software analyzed the possible active locations of the significantly affected genes in the cellular components of TQ-treated HL60 cells. The majority of genes were activated in the plasma membrane, which suggests that TQ affects signaling activation in the plasma membrane. The area of each category represents the percentages of involved genes to each other $(p<0.05)$.

Analyzing up- and downregulated genes separately showed their critical roles in specific biological processes (Tables 2 and 3).

DAVID analysis of the NGS results showed that the differentially expressed genes were primarily involved in signaling pathways, proliferation, angiogenesis, and apoptosis processes in leukemia cells. Some of these genes control the activation of the JAK/STAT and PI3K/AKT/mTOR signaling such as CCL2, CXCR2, and PRDM8.

Table 2. Biological process and molecular function of upregulated genes effected by TQ treatment.

\begin{tabular}{clccc}
\hline \multicolumn{1}{c}{ Category } & \multicolumn{1}{c}{ Term } & Similarity Score & $p$-Value & Genes \\
\hline GOTERM_BP_DIRECT & $\begin{array}{l}\text { Positive regulation of endothelial } \\
\text { cell migration }\end{array}$ & 1.00 & 0.0037 & ETS1, ADGRA2, and ANXA3 \\
\hline GOTERM_BP_DIRECT & Regulation of angiogenesis & 0.79 & 0.0037 & ETS1, ADGRA2, and ANXA3 \\
\hline GOTERM_BP_DIRECT & Positive regulation of angiogenesis & 1.00 & 0.021 & CXCL8,ETS1, and ANXA3 \\
\hline KEGG_PATHWAY & Pathways in cancer & 0.79 & 0.021 & CXCL8,ETS1, and ANXA3 \\
\hline GOTERM_BP_DIRECT & Oligodendrocyte development & 1.00 & 0.044 & PRDM8 and MYRF \\
\hline GOTERM_BP_DIRECT & Immune response & 1.00 & 0.049 & CXCL8, ETS1, and BPI \\
\hline GOTERM_BP_DIRECT & $\begin{array}{l}\text { Negative regulation of } \\
\text { cell proliferation }\end{array}$ & 0.85 & 0.049 & CXCL8,ETS1, and BPI \\
\hline GOTERM_MF_DIRECT & Ras GTPase binding & 1.00 & 0.029 & RAP1GAP and RAPGEF4 \\
\hline KEGG_PATHWAY & Rap1 signaling pathway & 0.79 & 0.029 & RAP1GAP and RAPGEF4 \\
\hline
\end{tabular}


Table 3. Biological process and molecular function of downregulated genes effected by TQ treatment.

\begin{tabular}{|c|c|c|c|c|}
\hline Category & Term & Similarity Score & $p$-Value & Genes \\
\hline GOTERM_BP_DIRECT & Cytokine-mediated signaling pathway & 1.00 & 0.000047 & $\begin{array}{l}\text { CCL2, CSF1R, IRF5, IL17RE, } \\
\text { IL6R, and RTN4R }\end{array}$ \\
\hline GOTERM_BP_DIRECT & $\begin{array}{l}\text { Positive regulation of ERK1 and } \\
\text { ERK2 cascade }\end{array}$ & 1.00 & 0.00019 & $\begin{array}{c}\text { CCL2, GPR183, GPR55, CHI3L1, } \\
\text { CSF1R, and FFAR4 }\end{array}$ \\
\hline GOTERM_BP_DIRECT & Inflammatory response & 1.00 & 0.00097 & $\begin{array}{l}\text { BCL6, CCL2, CXCR2, GPR68, } \\
\text { CHI3L1, CSF1R, and IL17RE }\end{array}$ \\
\hline UP_KEYWORDS & Inflammatory response & 0.81 & 0.00097 & $\begin{array}{l}\text { BCL6, CCL2, CXCR2, GPR68, } \\
\text { CHI3L1, CSF1R, and IL17RE }\end{array}$ \\
\hline GOTERM_BP_DIRECT & Cell surface receptor signaling pathway & 1.00 & 0.0014 & $\begin{array}{c}\text { CCL2, CXCR2, EPHA1, SAG, } \\
\text { ADGRG5, and ADRB2 }\end{array}$ \\
\hline GOTERM_BP_DIRECT & Immune response & 1.00 & 0.0088 & $\begin{array}{l}\text { CCL2, GPR183, CFP, IGLL1, } \\
\text { IL1RN, and PTGDR2 }\end{array}$ \\
\hline GOTERM_BP_DIRECT & Cell adhesion & 1.00 & 0.012 & $\begin{array}{c}\text { ATP1B1, CCL2, CASS4, EMILIN1, } \\
\text { MYBPH, and NINJ2 }\end{array}$ \\
\hline UP_KEYWORDS & Cell adhesion & 0.81 & 0.012 & $\begin{array}{c}\text { ATP1B1, CCL2, CASS4, EMILIN1, } \\
\text { MYBPH, and NINJ2 }\end{array}$ \\
\hline GOTERM_BP_DIRECT & Positive regulation of apoptotic process & 1.00 & 0.013 & $\begin{array}{c}\text { ADAMTSL4, BCL6, ARHGEF3, } \\
\text { S100B, and IRF5 }\end{array}$ \\
\hline GOTERM_BP_DIRECT & Positive regulation of cell proliferation & 1.00 & 0.013 & $\begin{array}{l}\text { CXCR2, EPHA1, S100B, CSF1R, } \\
\text { IL6R, and PRTN3 }\end{array}$ \\
\hline GOTERM_BP_DIRECT & $\begin{array}{l}\text { Cellular response to macrophage } \\
\text { colony-stimulating factor stimulus }\end{array}$ & 1.00 & 0.018 & CCL2 and CSF1R \\
\hline GOTERM_BP_DIRECT & Cell shape regulation & 0.79 & 0.018 & CCL2 and CSF1R \\
\hline GOTERM_BP_DIRECT & G protein-coupled receptor pathway & 1.00 & 0.018 & $\begin{array}{c}\text { CCL2, GPR141, GPR183, GPR55, } \\
\text { GPR68, ADGRG5, FFAR4, } \\
\text { and PTGDR2 }\end{array}$ \\
\hline GOTERM_MF_DIRECT & G protein-coupled receptor activity & 0.92 & 0.018 & $\begin{array}{c}\text { CCL2, GPR141, GPR183, GPR55, } \\
\text { GPR68, ADGRG5, FFAR4, } \\
\text { and PTGDR2 }\end{array}$ \\
\hline UP_KEYWORDS & Transducer & 0.79 & 0.018 & $\begin{array}{c}\text { CCL2, GPR141, GPR183, GPR55, } \\
\text { GPR68, ADGRG5, FFAR4, } \\
\text { and PTGDR2 } \\
\end{array}$ \\
\hline UP_KEYWORDS & G protein-coupled receptor & 0.79 & 0.018 & $\begin{array}{c}\text { CCL2, GPR141, GPR183, GPR55, } \\
\text { GPR68, ADGRG5, FFAR4, } \\
\text { and PTGDR2 }\end{array}$ \\
\hline GOTERM_BP_DIRECT & Relaxation of cardiac muscle & 1.00 & 0.036 & $A T P 1 B 1$ and $R G S 2$ \\
\hline KEGG_PATHWAY & cGMP-PKG signaling pathway & 0.79 & 0.036 & ATP1B1 and RGS2 \\
\hline GOTERM_BP_DIRECT & Protein O-linked fucosylation & 1.00 & 0.036 & ADAMTSL4 and CFP \\
\hline GOTERM_BP_DIRECT & $\begin{array}{l}\text { Complement activation, } \\
\text { alternative pathway }\end{array}$ & 1.00 & 0.039 & $C F D$ and $C F P$ \\
\hline GOTERM_BP_DIRECT & Positive regulation of angiogenesis & 1.00 & 0.048 & CXCR2, EPHA1, and CHI3L1 \\
\hline
\end{tabular}

\subsection{TQ Downregulated the Expression of JAK/STAT Pathways Genes}

RT-qPCR was used to confirm the expression changes of JAK2, STAT3, STAT5a, and $S T A T 5 b$ genes in HL60 cells after treatment with TQ (Figure 5). It was found that JAK2, STAT3, STAT5 $a$, and STAT5b gene expressions were significantly inhibited in TQ-treated cells $(p<0.001)$ compared with untreated cells as shown in Table 4. The NGS results also indicated a significant downregulation in targeted genes. 


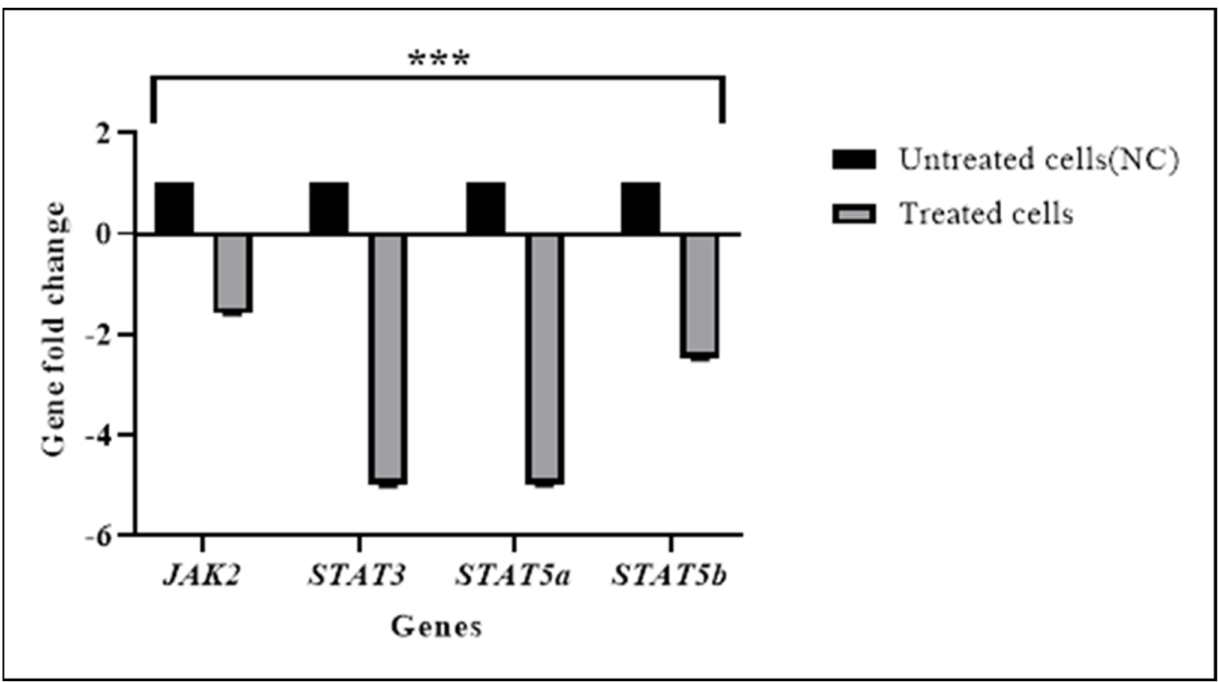

Figure 5. RT $-\mathrm{qPCR}$ results of JAK2, STAT3, STAT5a, and STAT5b expression in HL60 cells. The relative normalization of RT-qPCR showed that TQ significantly downregulated the expression of targeted genes in treated cells. STAT3 and STAT5a were downregulated in treated cells approximately 5 -fold lower compared with untreated cells. Data are presented as the mean \pm SEM. $\left({ }^{* * *} p<0.001\right)$.

Table 4. The fold change of JAK/STAT and genes in NGS and RT-qPCR.

\begin{tabular}{cccc}
\hline Genes & & Fold Change & \\
\hline & NGS & $p$-Value & RT-qPCR \\
\hline JAK2 & -0.52 & 0.006 & -1.6 \\
STAT3 & -0.31 & 0.012 & -5.0 \\
STAT5 $a$ & -0.31 & 0.025 & -5.0 \\
STAT5b & -0.49 & 0.001 & -2.5 \\
\hline
\end{tabular}

\subsection{TQ Downregulated the Expression of the PI3K/AKT Pathway Genes}

The results of RT-qPCR revealed significant downregulation of $A K T(p<0.001)$, PI3K $(p<0.001)$, and $m$ TOR $(p<0.001)$ expression in TQ-treated HL60 cells as shown in Table 5 and Figure 6. These results were consistent with the NGS results.

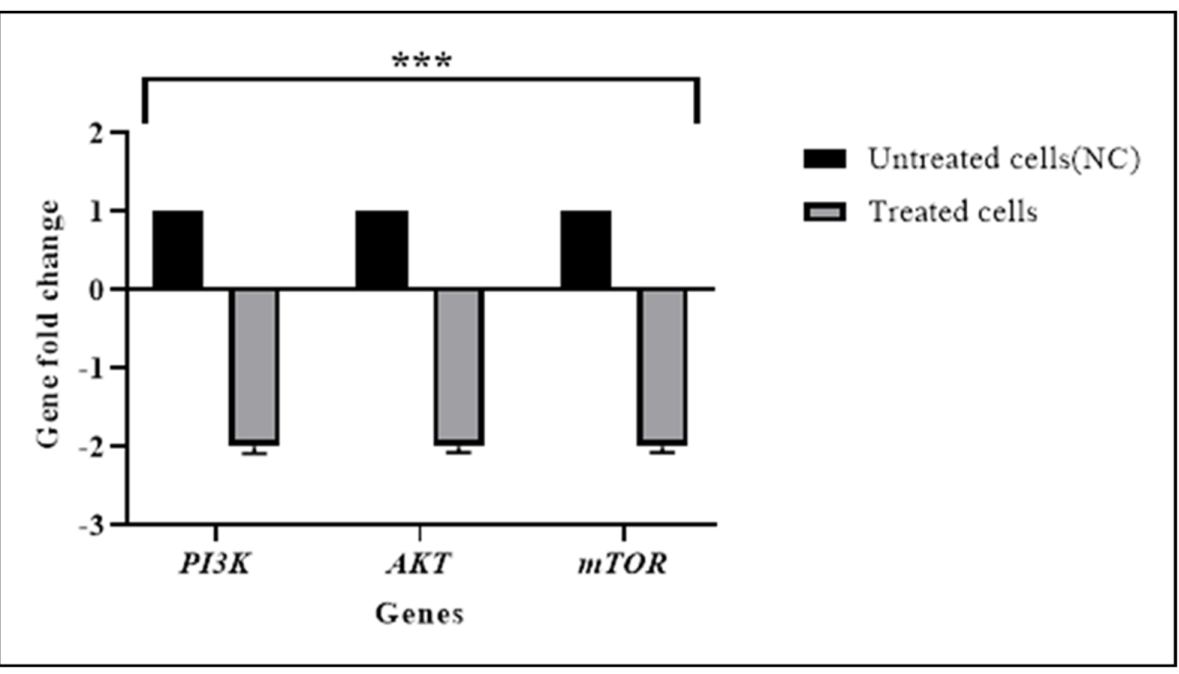

Figure 6. RT- $\mathrm{qPCR}$ results of PI3K, AKT, and mTOR expression in HL60 cells. The relative normalization of RT-qPCR showed that TQ significantly downregulated the expression of the targeted genes in treated cells. PI3K, AKT, and $m T O R$ were downregulated in treated cells approximately 2 -fold lower than in untreated cells. Data are presented as the mean $\pm \operatorname{SEM}\left({ }^{* * *} p<0.001\right)$. 
Table 5. The fold change of PI3K/AKT/mTOR genes in NGS and RT-qPCR.

\begin{tabular}{cccc}
\hline Genes & \multicolumn{3}{c}{ Fold Change } \\
\hline & NGS & $p$-Value & RT-qPCR \\
\hline AKT & -0.89 & 0.006 & -2.0 \\
PISK & -0.59 & 0.003 & -2.0 \\
mTOR & -0.26 & 0.043 & -2.0 \\
\hline
\end{tabular}

\subsection{TQ Downregulated the Expression of the c-Myc Gene}

This study aimed primarily to study the effect of TQ on c-Myc. Therefore, the effect of TQ on the c-Myc mRNA level was evaluated in HL60 cells by RT-qPCR (Figure 7). The results showed that TQ significantly decreased the expression of $c-M y c(p<0.001)$ (Table 6). The NGS and RT-qPCR both indicated downregulation of $c-M y c$ expression in TQ-treated cells.

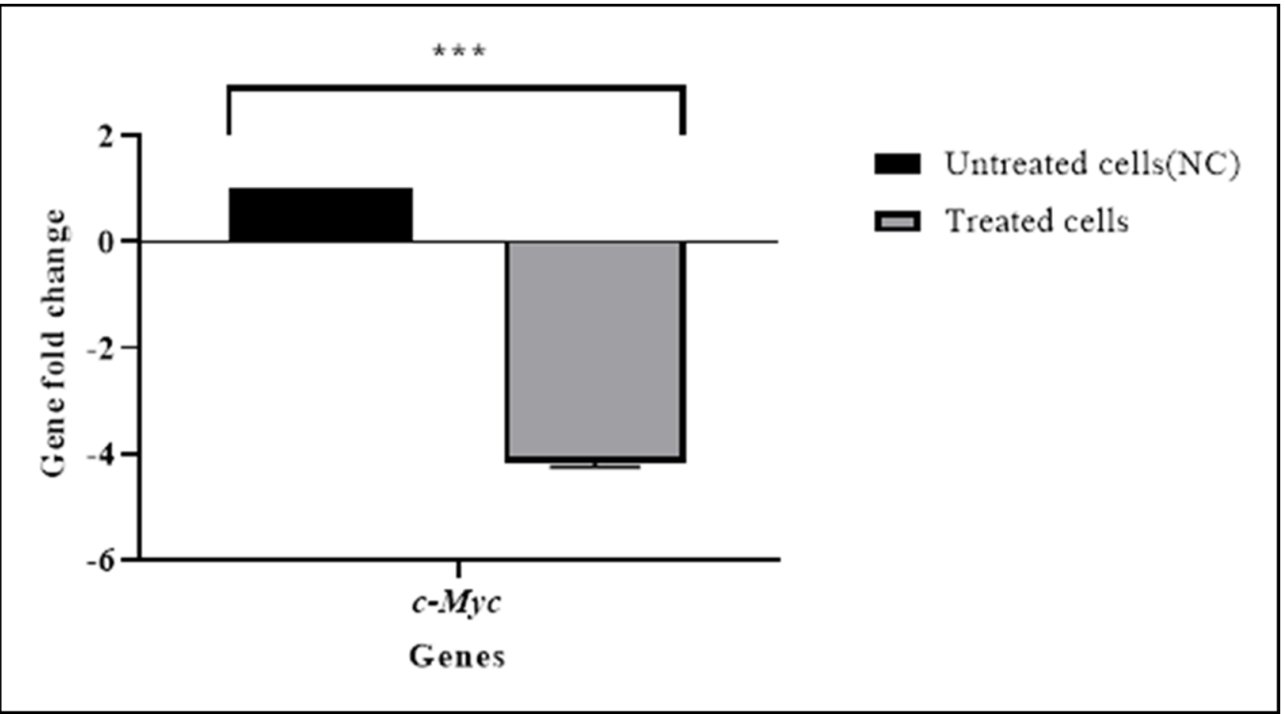

Figure 7. The $c-M y c$ expression level was determined using a RT-qPCR assay in HL60 cells. RT - qPCR revealed that TQ significantly downregulated $c-M y c$ gene expression by $4-$ fold in treated cells, and the untreated cells were used as a negative control group. Data are presented as the mean $\pm \operatorname{SEM}\left({ }^{* * *} p<0.001\right)$.

Table 6. The fold change of the $c-M y c$ gene in NGS and RT-qPCR.

\begin{tabular}{cccc}
\hline Genes & & Fold Change & \\
\hline & NGS & $p$-Value & RT-qPCR \\
\hline$c-M y c$ & -0.625 & 0.00001 & -4.16 \\
\hline
\end{tabular}

According to the results of the current study, TQ reduced the gene expression of $c-M y c$ by inhibiting the expression of JAK/STAT and PI3K/AKT/mTOR genes including JAK2, STAT3, STAT5a, STAT5b, PI3K, AKT, and mTOR.

\subsection{TQ Inhibited JAK/STAT Signaling}

Jess assay Western blotting analysis was performed to examine the effect of TQ on JAK/STAT signaling in HL60 leukemia cells. The cells were incubated with $2 \mu \mathrm{M}$ TQ for $48 \mathrm{~h}$; then, the protein was extracted from treated and untreated HL60 leukemia cells for the protein analysis. The results showed that TQ significantly suppressed the expression of JAK2, STAT3, and STAT5 proteins $(p<0.001)$ (Figure 8 ). The results also revealed that TQ 
inhibited the activation of JAK/STAT signaling through dephosphorylation of STAT3 and STAT5 proteins.

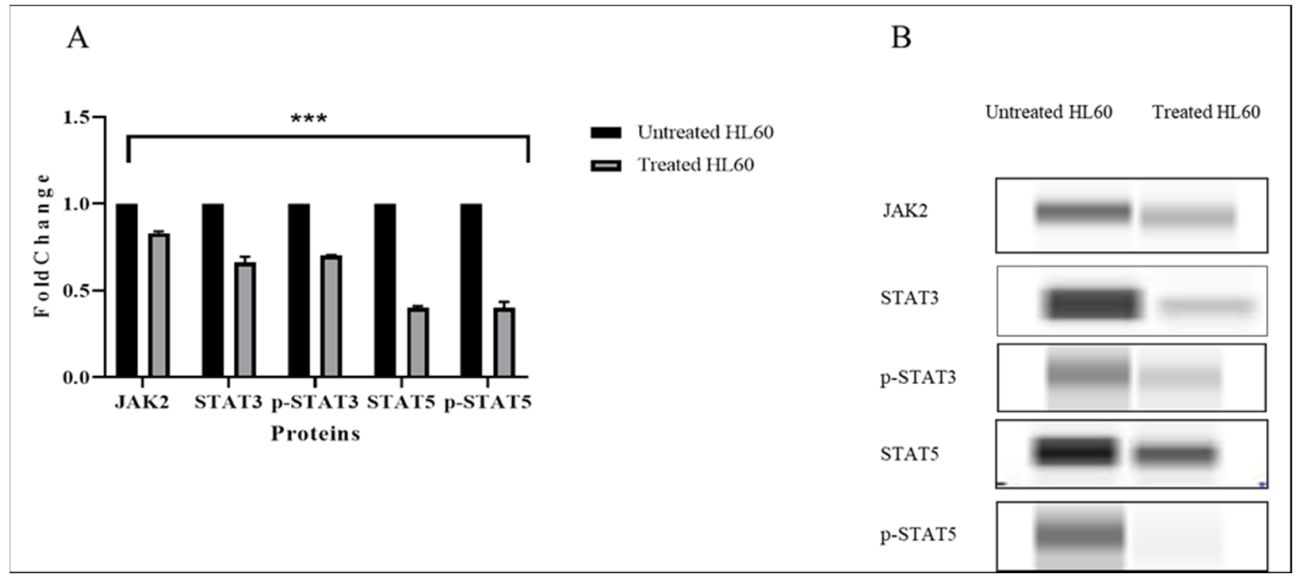

Figure 8. Effects of TQ on the expression of JAK/STAT proteins in HL60 cells. (A) JAK2, STAT3, p-STAT3, STAT5, and p-STAT5 protein expression in TQ-treated cells compared with untreated cells or negative control. Data are presented as the mean \pm SEM $(* * *<0.001)$. (B) Images of JAK2, STAT3, p-STAT3, STAT5, and p-STAT5 protein expression from capillary Western blotting in treated and untreated HL60 cells.

\subsection{TQ Inhibited PI3K/AKT Signaling}

The effect of TQ treatment was examined on PI3K/AKT protein expression (Figure 9). The expression of PI3K and AKT. The results revealed that PI3K and AKT protein expression decreased significantly in the TQ-treated samples $(p<0.001)$. In addition, TQ treatment significantly dephosphorylated PI3K and AKT $(p<0.01)$. Furthermore, the PI3K/AKT negative regulator protein, PTEN, was also detected. TQ increased PTEN protein expression significantly in treated cells $(p<0.001)$.

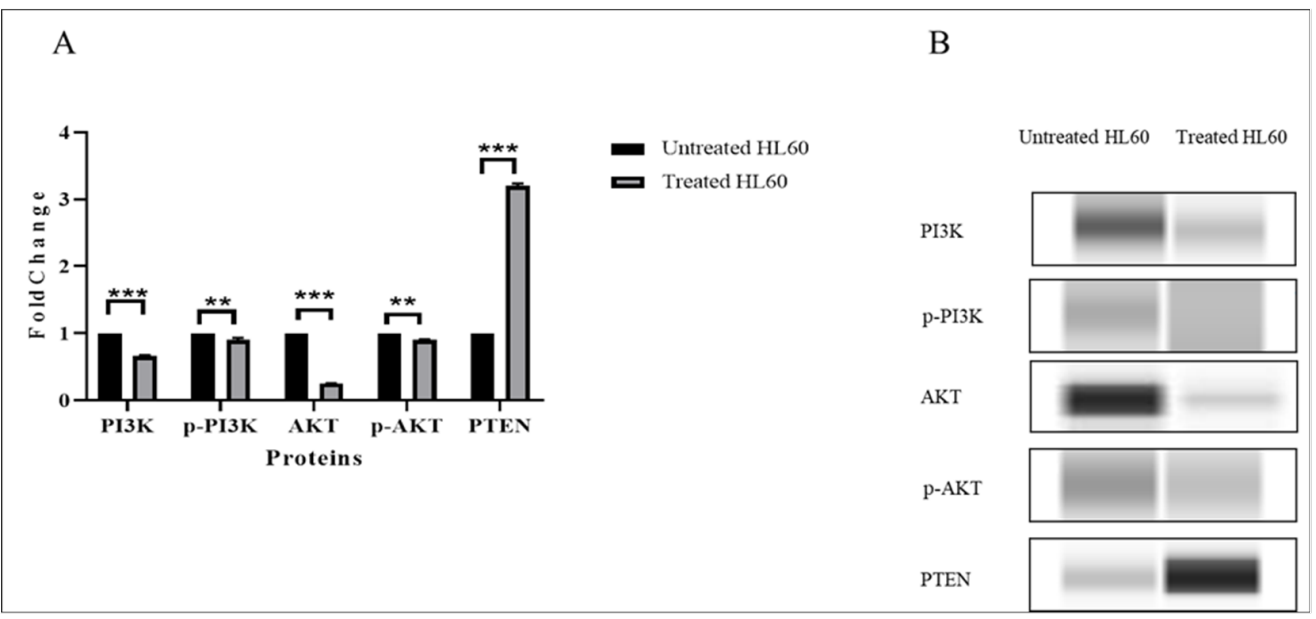

Figure 9. Effects of TQ on the expression of PI3K/AKT proteins in HL60 cells. (A) PI3K, p-PI3K, AKT, $\mathrm{p}$-AKT, and PTEN protein expression in TQ-treated cells compared with untreated cells or negative control. Data are presented as the mean \pm SEM $\left(^{* * *} p<0.001{ }^{* *} p<0.01\right)$. (B) Image of PI3K, p-PI3K, $\mathrm{AKT}, \mathrm{p}-\mathrm{AKT}$, and PTEN protein expression from capillary Western blotting in treated and untreated HL60 cells.

\subsection{TQ Inhibited c-Myc Protein Expression}

As shown in Figure 10, the effect of TQ on c-Myc protein expression in HL-60 cells was also examined, and the results showed a marked decrease in c-Myc protein after TQ treatment $\left({ }^{* * *} p<0.001\right)$. 


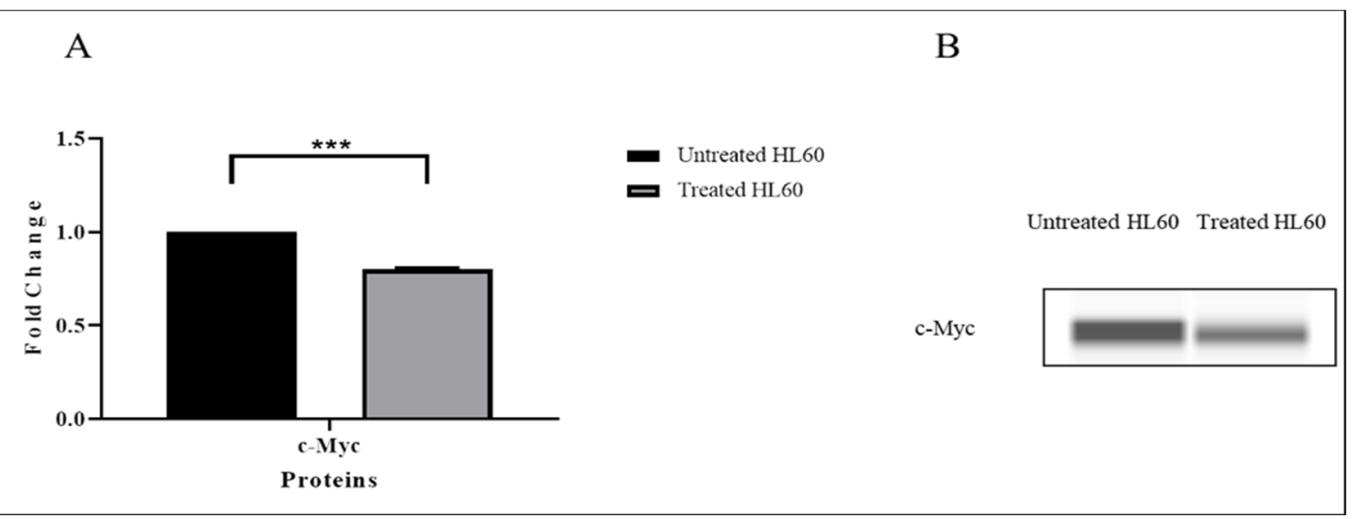

Figure 10. Effects of TQ on the expression of c-Myc protein in HL60 cells. (A) c-Myc protein expression in TQ-treated cells compared with untreated cells or negative control. Data are presented as the mean \pm SEM $(* * *<0.001)$. (B) Image of c-Myc protein expression from capillary Western blotting in treated and untreated HL60 cells.

Based on these results, TQ inhibited the protein expression and phosphorylation of JAK/STAT and $\mathrm{PI} 3 \mathrm{~K} / \mathrm{AKT} / \mathrm{mTOR}$ proteins, resulting in the inhibition of c-Myc protein expression.

\section{Discussion}

The c-Myc proto-oncogene is markedly expressed in the HL60 cell [3]. C-Myc has a crucial role in leukemogenesis through inducing proliferation and inhibiting apoptosis in leukemia cells [32]. The overexpression of c-Myc in cancers is correlated with chemotherapy resistance [33]. Drugs cannot directly target the c-Myc gene [6]. Thus, alternative indirect methods to suppress c-Myc function are vitally needed. The JAK/STAT and $\mathrm{PI} 3 \mathrm{~K} / \mathrm{AKT} / \mathrm{mTOR}$ pathways are constitutively activated in leukemia leading to c-Myc overexpression $[34,35]$. Therefore, the current study aimed to determine the effect of TQ on c-Myc by affecting upstream c-Myc regulators: the JAK/STAT and PI3K/AKT/mTOR signaling pathways.

The current study investigated the molecular effect mechanisms of TQ on HL60 AML cells. NGS analysis was performed to study the mRNA changes in leukemia cells treated with $2 \mu \mathrm{M}$ TQ compared to untreated cells. Fifty-four significantly upregulated genes and 60 significantly upregulated genes associated with TQ treatment were identified in a dose- and time-dependent manner. The 114 affected genes were analyzed by DAVID analysis, which showed that the efficacy of TQ in treating leukemia cells may be related to the biological process of cell proliferation., apoptosis, immune and inflammatory response, and angiogenesis.

The NGS results showed downregulation of JAK/STAT and PI3K/AKT/mTOR genes in TQ-treated cells. The results also revealed significant downregulation in genes that induced the activation of JAK/STAT and PI3K/AKT/mTOR pathways (Figure 11) such as chemokine (C-C motif) ligand 2 (CCL2) [36], colony-stimulating factor 1 receptor (CSF1R) [37], CXC chemokine receptor 2 (CXCR2) [38], interleukin 6 receptor (IL6R) [39], G protein-coupled receptors (GPCRs) [40], and chitinase 3 like 1 protein (Chi3L1) [41]. These findings suggest that TQ induces apoptosis and inhibits cancer cell proliferation by inhibiting the JAK/STAT and PI3K/AKT/mTOR signaling pathways. This suggestion is supported by previous studies where TQ induced apoptosis by inhibiting the activation of the PI3K/AKT pathway in the oral squamous carcinoma KB cell line [42] and inhibited cell proliferation through suppression of the JAK/STAT pathway in human multiple myeloma cells [43]. In contrast, our results showed the upregulation of genes that functioned to inhibit the JAK/STAT and PI3K/AKT/mTOR pathways' activation including PRDI-BF1 and RIZ homology domain-containing 8 (PRDM8) [44] and RAP1 GTPase activating protein $(R A P 1 G A P)$ [45]. In the present study, there was a significant upregulation of PRDM8 $(p<0.044)$ and RAP1GAP $(p<0.029)$ in TQ-treated HL60 leukemia cells, suggesting that TQ 
inhibited HL60 cell growth and suppressed c-Myc expression by inhibition of JAK/STAT and PI3K/AKT/mTOR signaling through upregulation of PRDM8 and RAP1GAP.

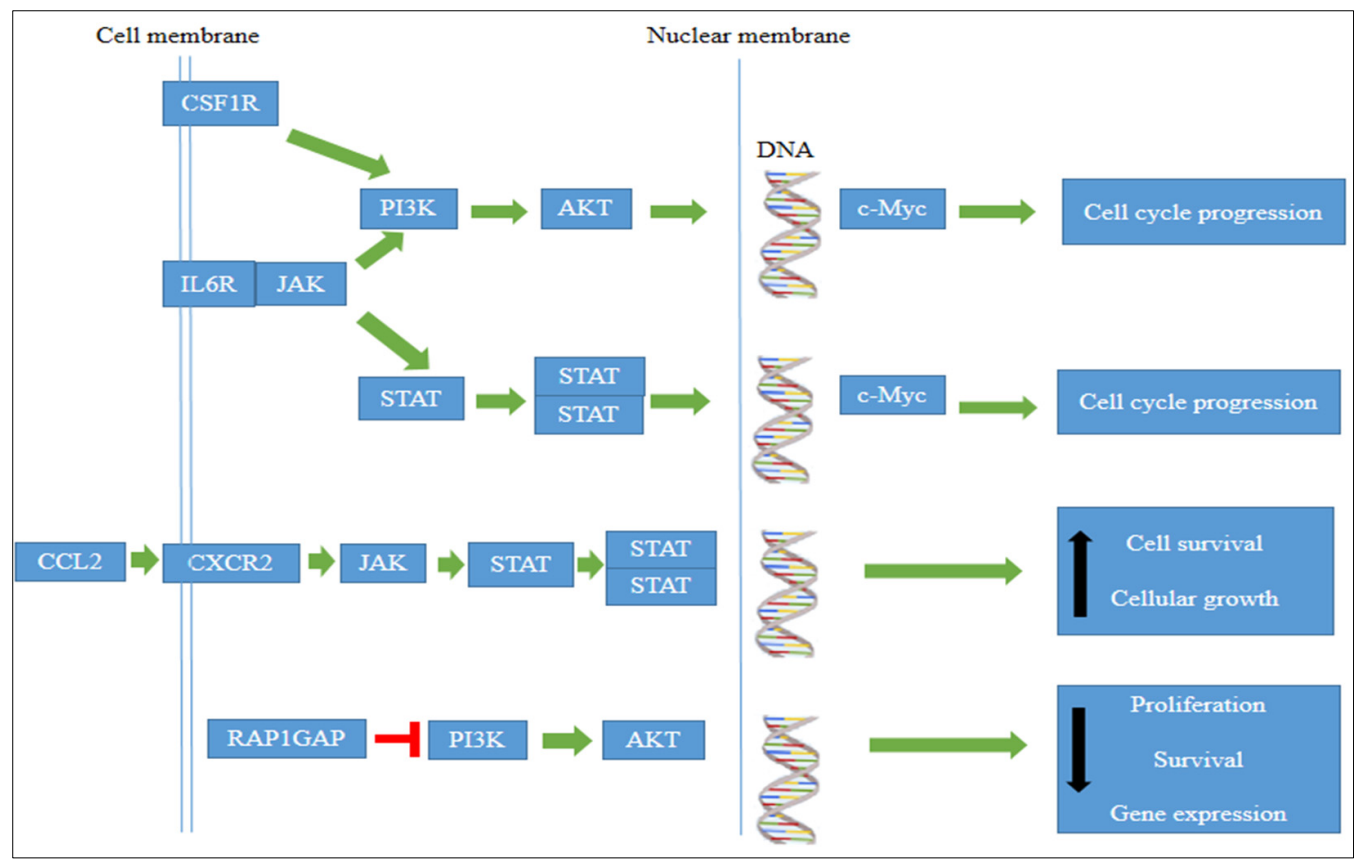

Figure 11. Image showing how significantly expressed genes affect JAK/STAT, PI3K/AKT, and c-Myc activation. Adapted from DAVIVD software.

In order to verify the effect of TQ on the regulation of gene expression in the JAK/STAT and PI3K/AKT/mTOR pathways, the JAK2, STAT3, STAT5a, STAT5b, PI3K, AKT, mTOR, and $c-M y c$ genes were selected for further gene expression analysis using RT-qPCR. Our results showed that TQ inhibited JAK/STAT and PI3K/AKT/mTOR pathways by downregulating the mRNA expression of targeted genes. Previous reports demonstrated that inhibition of the STAT3/c-Myc was associated with induced apoptosis in esophageal adenocarcinoma cells [46]. Similarly, the current RT-qPCR results showed that downregulated STAT3 and $c-M y c$ in treated HL60 leukemia cells with TQ was associated with a significant increase in cell apoptosis $(p<0.001)$. These findings suggest that TQ induced cell apoptosis in HL60 leukemia cells by inhibiting STAT3 and c-Myc expression. Additionally, inhibition of STAT5/c-Myc significantly reduced the cell proliferation of cervical cancer cells [47]. In agreement, the present study revealed downregulation of STAT5 and $c-M y c$ and inhibition of cell proliferation with apoptosis induction after TQ treatment of HL60 leukemia cells, suggesting that TQ inhibits cell proliferation and induces apoptosis of HL60 leukemia cells by inhibiting the STAT5/c-Myc mediated signaling. These findings are also supported by our previous published studies in which TQ induced downregulation of JAK2, STAT3, and STAT5 and a consequent proliferation inhibition and apoptosis induction in MV4-11 AML cells [48] and K562 chronic myeloid leukemia cells [49].

Moreover, PI3K/AKT exerts a specific biological function by upregulating the expression of $c-M y c$, and the PI3K/AKT/c-Myc axis is a valid therapeutic target in treating esophageal squamous cell carcinoma [50]. The use of PI3K/AKT/mTOR inhibitors downregulates $c-M y c$ expression and enhances the anti-leukemic effects of the leukemia drug, all-trans retinoic acid (ATRA), in AML cell lines and primary patient samples [51]. Similarly, our findings showed downregulation of PI3K, AKT, and mTOR genes associated with $c-M y c$ downregulation and proliferation reduction in TQ-treated HL60 cells.

Upon stimulation, JAK phosphorylates STAT proteins causing STAT dimerization and nucleus translocation, where they bind to DNA and regulate the transcription of target genes such as $c-M y c$ [52]. The protein analysis results in the current study showed that TQ treatment reduced the phosphorylation of JAK2, STAT3, and STAT5 proteins. Our 
findings are consistent with what has previously been reported: that TQ suppressed STAT3 phosphorylation at Tyr705 due to the inhibition of JAK2 activity in gastric cancer [53]. Moreover, TQ treatment reduces the upstream effectors of STAT5, such as KIT and FLT3, leading to dephosphorylate STAT5 in leukemia cells [54]. In addition, our results show that TQ treatment reduces the expression levels of p-PI3K and p-AKT proteins in leukemia cells and induces phosphatase and tensin homolog (PTEN) expression, which is considered protein tyrosine phosphatases in the PI3K/AKT pathway and tumor suppressor [55], suggesting that TQ inhibits the protein synthesis and phosphorylation of the PI3K/AKT pathway through activation of negative regulator PTEN.

The results of the current study showed that TQ inhibited the c-Myc protein expression in HL60 cells. Recent reports have shown that TQ treatment decreases the c-Myc level in AML cells [56]. Additionally, many studies confirm a principal role of c-Myc in proliferation, cell cycle regulation, apoptosis, and differentiation in AML [57], suggesting that TQ reduces the proliferation of AML through inhibiting c-Myc. We hypothesized that TQ-mediated c-Myc downregulation inhibits the upstream regulators: signaling pathways such as JAK/STAT and PI3K/AKT/mTOR. Consistent with the previous report, TQ treatment in this study significantly decreased c-Myc protein expression levels in treated HL60 cells compared with untreated cells. These data suggest that TQ decreases c-Myc protein expression through inhibiting the JAK/STAT and PI3K/AKT/mTOR signaling pathways in HL60 cells.

\section{Conclusions}

Our findings confirm the potential effects of TQ in inhibiting cell proliferation and inducing apoptosis of HL60 leukemia cells through indirectly targeting c-Myc oncogene expression by inhibiting JAK/STAT and PI3K/AKT/mTOR signaling. The findings of the present study nominate the c-Myc as a therapeutic target and TQ as a potential candidate for the treatment of AML patients. However, further studies are required to investigate the effect of TQ on AML in vivo experiments.

Author Contributions: Conceptualization, H.A.N.A.-J. and B.A.; methodology, H.A.N.A.-J. and B.A.; software, B.A.; validation, H.A.N.A.-J., N.M.A.-T. and M.A.; formal analysis, M.A. and B.A.; investigation, W.R.W.T., I.I. and M.F.J.; resources, H.A.N.A.-J. and M.F.J.; data curation, W.N.I., A.S.A.-W., W.R.W.T. and F.A.A.-R.; writing-original draft preparation, B.A. and H.A.N.A.-J.; writing-review and editing, H.A.N.A.-J., B.A., M.F.J., W.R.W.T., A.S.A.-W. and W.N.I.; visualization, B.A. and H.A.N.A.-J.; supervision, H.A.N.A.-J.; project administration, H.A.N.A.-J.; funding acquisition, H.A.N.A.-J. All authors have read and agreed to the published version of the manuscript.

Funding: This work was funded by the Fundamental Research Grant Scheme of the Ministry of Education, Malaysia [FRGS/1/2019/SKK08/UNISZA/02/3 (RR330)].

Institutional Review Board Statement: Not applicable.

Informed Consent Statement: Not applicable.

Data Availability Statement: Data is contained within the article.

Acknowledgments: The authors would like to thank all staff at the Cell Culture and Molecular Laboratories, Medical Campus, Universiti Sultan Zainal Abidin (UniSZA), for their cooperation.

Conflicts of Interest: The authors declare no conflict of interest.

\section{References}

1. Yamamoto, J.-F.; Goodman, M.-T. Patterns of leukemia incidence in the United States by subtype and demographic characteristics, 1997-2002. Cancer Causes Control 2008, 19, 379-390. [CrossRef] [PubMed]

2. Bullinger, L.; Döhner, K.; Döhner, H. Genomics of acute myeloid leukemia diagnosis and pathways. J. Clin. Oncol. 2017, 35, 934-946. [CrossRef] [PubMed]

3. Maniwa, Y.; Kasukabe, T.; Kumakura, S. Vitamin K2 and cotylenin A synergistically induce monocytic differentiation and growth arrest along with the suppression of c-MYC expression and induction of cyclin G2 expression in human leukemia HL-60 cells. Int. J. Oncol. 2015, 47, 473-480. [CrossRef] [PubMed] 
4. Letellier, E.; Haan, S. SOCS2: Physiological and pathological functions. Front. Biosci. 2016, 8, $189-204$.

5. Song, W.; Liu, M.-G.; Zhang, J.-B.; Zhang, J.-J.; Sun, M.-M.; Yu, Q.-K. Mechanism of action of EBV, Bcl-2, p53, c-Myc and Rb in non-Hodgkin's lymphoma. Eur. Rev. Med. Pharmacol. Sci. 2016, 20, 1093-1097. [PubMed]

6. Chen, H.; Liu, H.; Qing, G. Targeting oncogenic Myc as a strategy for cancer treatment. Signal Transduct. Target. Ther. 2018, 3, 5. [CrossRef]

7. Reddy, D.; Kumavath, R.; Ghosh, P.; Barh, D. Lanatoside C induces G2/M cell cycle arrest and suppresses cancer cell growth by attenuating MAPK, Wnt, JAK-STAT, and PI3K/AKT/mTOR signaling pathways. Biomolecules 2019, 9, 792. [CrossRef]

8. Elekofehinti, O.-O.; Oyedokun, V.-O.; Iwaloye, O.; Lawal, A.-O.; Ejelonu, O.-C. Momordica charantia silver nanoparticles modulate S OCS/JAK/STAT and P13K/Akt/PTEN signalling pathways in the kidney of streptozotocin-induced diabetic rats. J. Diabetes Metab. Disord. 2021, 20, 245-260. [CrossRef]

9. McCubrey, J.-A.; Steelman, L.-S.; Abrams, S.-L.; Bertrand, F.-E.; Ludwig, D.-E.; Bäsecke, J.; Libra, M.; Stivala, F.; Milella, M.; Tafuri, A. Targeting survival cascades induced by activation of Ras/Raf/MEK/ERK, PI3K/PTEN/Akt/mTOR and Jak/STAT pathways for effective leukemia therapy. Leukemia 2008, 22, 708-722. [CrossRef]

10. Steelman, L.S.; Pohnert, S.C.; Shelton, J.G.; Franklin, R.A.; Bertrand, F.E.; McCubrey, J.A. JAK/STAT, Raf/MEK/ERK, PI3K/Akt and BCR-ABL in cell cycle progression and leukemogenesis. Leukemia 2004, 18, 189-218. [CrossRef]

11. Shah, A.; Andersson, T.; Rachet, B.; Björkholm, M.; Lambert, P.-C. Survival and cure of acute myeloid leukaemia in E ngland, 1971-2006: A population-based study. Br. J. Haematol. 2013, 162, 509-516. [CrossRef]

12. Almajali, B.; Al-Jamal, H.A.N.; Taib, W.R.W.; Ismail, I.; Johan, M.F.; Doolaanea, A.A.; Ibrahim, W.N. Thymoquinone, as a Novel Therapeutic Candidate of Cancers. Pharmaceuticals 2021, 14, 369. [CrossRef] [PubMed]

13. AlGhamdi, A.-A.; Mohammed, M.-R.; Zamzami, M.-A.; Al-Malki, A.-L.; Qari, M.-H.; Khan, M.-I.; Choudhry, H. Untargeted Metabolomics Identifies Key Metabolic Pathways Altered by Thymoquinone in Leukemic Cancer Cells. Nutrients 2020, $12,1792$. [CrossRef]

14. Almajali, B.; Al-Jamal, H.A.N.; Taib, W.R.W.; Ismail, I.; Johan, M.F.; Doolaanea, A.-A.; Ibrahim, W.-N.; Tajudin, S.-A. Thymoquinone Suppresses Cell Proliferation and Enhances Apoptosis of HL60 Leukemia Cells through Re-Expression of JAK/STAT Negative Regulators. Asian Pac. J. Cancer Prev. 2021, 22, 879-885. [CrossRef] [PubMed]

15. Network, Cancer Genome Atlas Research. Genomic and epigenomic landscapes of adult de novo acute myeloid leukemia. N. Engl. J. Med. 2013, 368, 2059-2074. [CrossRef] [PubMed]

16. Papaemmanuil, E.; Gerstung, M.; Bullinger, L.; Gaidzik, V.-I.; Paschka, P.; Roberts, N.-D.; Potter, N.-E.; Heuser, M.; Thol, F.; Bolli, N. Genomic classification and prognosis in acute myeloid leukemia. N. Engl. J. Med. 2016, 374, 2209-2221. [CrossRef]

17. Gatt, L.; Saliba, D.G.; Schembri-Wismayer, P.; Zammit-Mangion, M. Tyrosol, at the Concentration Found in Maltese Extra Virgin Olive Oil, Induces HL-60 Differentiation towards the Monocyte lineage. Appl. Sci. 2021, 11, 10199. [CrossRef]

18. Chen, S.; Zhou, Y.; Chen, Y.; Gu, J. fastp: An ultra-fast all-in-one FASTQ preprocessor. Bioinformatics 2018, 34, i884-i890. [CrossRef]

19. Dobin, A.; Davis, C.-A.; Schlesinger, F.; Drenkow, J.; Zaleski, C.; Jha, S.; Batut, P.; Chaisson, M.; Gingeras, T.-R. STAR: Ultrafast universal RNA-seq aligner. Bioinformatics 2013, 29, 15-21. [CrossRef]

20. Liao, Y.; Smyth, G.-K.; Shi, W. FeatureCounts: An efficient general purpose program for assigning sequence reads to genomic features. Bioinformatics 2014, 30, 923-930. [CrossRef]

21. Love, M.-I.; Huber, W.; Anders, S. Moderated estimation of fold change and dispersion for RNA-seq data with DESeq2. Genome Biol. 2014, 15, 550. [CrossRef] [PubMed]

22. Sherman, B.-T.; Tan, Q.; Collins, J.-R.; Alvord, W.-G.; Roayaei, J.; Stephens, R.; Baseler, M.-W.; Lane, H.-C.; Lempicki, R.-A. The DAVID Gene Functional Classification Tool: A novel biological module-centric algorithm to functionally analyze large gene lists. Genome Biol. 2007, 8, R183.

23. Livak, K.-J.; Schmittgen, T.-D. Analysis of relative gene expression data using real-time quantitative PCR and the $2-\Delta \Delta C T$ method. Methods 2001, 25, 402-408. [CrossRef] [PubMed]

24. Gupta, M.; Han, J.; Stenson, M.; Maurer, M.; Wellik, L.; Hu, G.; Ziesmer, S.; Dogan, A.; Witzig, T.-E. Elevated serum IL-10 levels in diffuse large B-cell lymphoma: A mechanism of aberrant JAK2 activation. Am. J. Hematol. 2012, 119, 2844-2853. [CrossRef] [PubMed]

25. Bellon, M.; Moles, R.; Chaib-Mezrag, H.; Pancewicz, J.; Nicot, C. JAG1 overexpression contributes to Notch1 signaling and the migration of HTLV-1-transformed ATL cells. J. Hematol. Oncol. 2018, 11, 119. [CrossRef]

26. Rahat, B.; Thakur, S.; Bagga, R.; Kaur, J. Epigenetic regulation of STAT5A and its role as fetal DNA epigenetic marker during placental development and dysfunction. Placenta 2016, 44, 46-53. [CrossRef]

27. Loaiza Cantù, C.; Ierardi, R.; Alborelli, I.; Fugazza, C.; Cassinelli, L.; Piconese, S.; Bose, F.; Ottolenghi, S.; Ferrari, G.; Ronchi, A. Sox6 enhances erythroid differentiation in human erythroid progenitors. Am. J. Hematol. 2011, 117, 3669-3679.

28. Chen, M.; Lu, J.; Wei, W.; Lv, Y.; Zhang, X.; Yao, Y.; Wang, L.; Ling, T.; Zou, X. Effects of proton pump inhibitors on reversing multidrug resistance via downregulating V-ATPases/PI3K/Akt/mTOR/HIF-1 $\alpha$ signaling pathway through TSC1/2 complex and Rheb in human gastric adenocarcinoma cells in vitro and in vivo. OncoTargets Ther. 2018, 11, 6705. [CrossRef]

29. Yi, W.; Li, D.; Guo, Y.; Zhang, Y.; Huang, B.; Li, X. Sevoflurane inhibits the migration and invasion of glioma cells by upregulating microRNA-637. Int. J. Mol. Med. 2016, 38, 1857-1863. [CrossRef]

30. Yu, Q.; Zhou, X.; Xia, Q.; Shen, J.; Yan, J.; Zhu, J.; Li, X.; Shu, M. Long non-coding RNA CCAT1 that can be activated by c-Myc promotes pancreatic cancer cell proliferation and migration. Am. J. Transl. Res. 2016, 8, 5444. 
31. Darwish, W.-S.; Ikenaka, Y.; Nakayama, S.; Mizukawa, H.; Ishizuka, M. Constitutive Effects of Lead on Aryl Hydrocarbon Receptor Gene Battery and Protection by $\beta$-carotene and Ascorbic Acid in Human HepG2 Cells. J. Food Sci. 2016, 81, T275-T281. [CrossRef]

32. Bashash, D.; Sayyadi, M.; Safaroghli-Azar, A.; Sheikh-Zeineddini, N.; Riyahi, N.; Momeny, M. Small molecule inhibitor of c-Myc 10058-F4 inhibits proliferation and induces apoptosis in acute leukemia cells, irrespective of PTEN status. Int. J. Biochem. Cell Biol. 2019, 108, 7-16. [CrossRef]

33. Pan, X.-N.; Chen, J.-J.; Wang, L.-X.; Xiao, R.-Z.; Liu, L.-L.; Fang, Z.-G.; Liu, Q.; Long, Z.-J.; Lin, D.-J. Inhibition of c-Myc overcomes cytotoxic drug resistance in acute myeloid leukemia cells by promoting differentiation. PLoS ONE 2014, 9, e105381. [CrossRef]

34. Al-Jamal, H.A.N.; Johan, M.F.; Jusoh, S.A.M.; Ismail, I.; Taib, W.R.W. Re-expression of bone marrow proteoglycan-2 by 5azacytidine is associated with STAT3 inactivation and sensitivity response to imatinib in resistant CML cells. Asian Pac. J. Cancer Prev. 2018, 19, 1585.

35. Zhang, B.; Zhou, P.; Li, X.; Shi, Q.; Li, D.; Ju, X. Bitterness in sugar: O-GlcNAcylation aggravates pre-B acute lymphocytic leukemia through glycolysis via the PI3K/Akt/c-Myc pathway. Am. J. Cancer Res. 2017, 7, 1337.

36. Mizutani, K.; Sud, S.; McGregor, N.-A.; Martinovski, G.; Rice, B.-T.; Craig, M.-J.; Varsos, Z.-S.; Roca, H.; Pienta, K.-J. The chemokine CCL2 increases prostate tumor growth and bone metastasis through macrophage and osteoclast recruitment. Neoplasia 2009, 11, 1235-1242. [CrossRef]

37. Rattanaburee, T.; Tipmanee, V.; Tedasen, A.; Thongpanchang, T.; Graidist, P. Inhibition of CSF1R and AKT by ( \pm )-kusunokinin hinders breast cancer cell proliferation. Biomed. Pharmacother. 2020, 129, 110361. [CrossRef]

38. Shang, F.-M.; Li, J. A small-molecule antagonist of CXCR1 and CXCR2 inhibits cell proliferation, migration and invasion in melanoma via PI3K/AKT pathway. Med. Clin. 2019, 152, 425-430. [CrossRef]

39. Denley, S.-M.; Jamieson, N.-B.; McCall, P.; Oien, K.-A.; Morton, J.-P.; Carter, C.-R.; Edwards, J.; McKay, C.-J. Activation of the IL-6R/Jak/stat pathway is associated with a poor outcome in resected pancreatic ductal adenocarcinoma. J. Gastrointest. Surg. 2013, 17, 887-898. [CrossRef]

40. Chen, J.; Lan, T.; Zhang, W.; Dong, L.; Kang, N.; Zhang, S.; Fu, M.; Liu, B.; Liu, K.; Zhan, Q. Feed-forward reciprocal activation of PAFR and STAT3 regulates epithelial-mesenchymal transition in non-small cell lung Cancer. Cancer Res. 2015, 75, 4198-4210. [CrossRef] [PubMed]

41. Park, K.-R.; Yun, H.-M.; Yoo, K.; Ham, Y.-W.; Han, S.-B.; Hong, J.-T. Chitinase 3 like 1 suppresses the stability and activity of p53 to promote lung tumorigenesis. Cell Commun. Signal. 2020, 18, 1-13. [CrossRef]

42. Ren, X.; Luo, W. Exploration of pro-apoptotic effect of Thymoquinone on oral squamous cell carcinoma cells through PI3K/Akt signaling pathway. Mol. Cell Biol. 2019, 65, 61-64. [CrossRef]

43. Li, F.; Rajendran, P.; Sethi, G. Thymoquinone inhibits proliferation, induces apoptosis and chemosensitizes human multiple myeloma cells through suppression of signal transducer and activator of transcription 3 activation pathway. Br. J. Pharmacol. 2010, 161, 541-554. [CrossRef]

44. Chen, Z.; Gao, W.; Pu, L.; Zhang, L.; Han, G.; Zuo, X.; Zhang, Y.; Li, X.; Shen, H.; Wu, J. PRDM8 exhibits antitumor activities toward hepatocellular carcinoma by targeting NAP1L1. Hepatology 2018, 68, 994-1009. [CrossRef]

45. Wang, N.; Li, Y.; Wei, J.; Pu, J.; Liu, R.; Yang, Q.; Guan, H.; Shi, B.; Hou, P.; Ji, M. TBX1 functions as a tumor suppressor in thyroid cancer through inhibiting the activities of the PI3K/AKT and MAPK/ERK pathways. Thyroid 2019, 29, 378-394. [CrossRef]

46. Su, W.; Guo, C.; Wang, L.; Wang, Z.; Yang, X.; Niu, F.; Tzou, D.; Yang, X.; Huang, X.; Wu, J. LncRNA MIR22HG abrogation inhibits proliferation and induces apoptosis in esophageal adenocarcinoma cells via activation of the STAT3/c-Myc/FAK signaling. Aging 2019, 11, 4587. [CrossRef]

47. Chen, Y.; Han, L.; Bai, L.; Tang, H.; Zheng, A. Trichosanthin inhibits the proliferation of cervical cancer cells and downregulates STAT-5/C-myc signaling pathway. Pathol. Res. Pract. 2019, 215, 632-638. [CrossRef]

48. Al-Rawashde, F.A.; Johan, M.F.; Taib, W.R.W.; Ismail, I.; Johari, S.A.T.T.; Almajali, B.; Al-Wajeeh, A.S.; Nazari, V.M.; Al-Jamal, H.A.N. Thymoquinone Inhibits Growth of Acute Myeloid Leukemia Cells through Reversal SHP-1 and SOCS-3 Hypermethylation: In Vitro and In Silico Evaluation. Pharmaceuticals 2021, 14, 1287. [CrossRef]

49. Al-Rawashde, F.A.; Wan Taib, W.R.; Ismail, I.; Johan, M.F.; Al-Wajeeh, A.S.; Al-Jamal, H.A.N. Thymoquinone Induces Downregulation of BCR-ABL/JAK/STAT Pathway and Apoptosis in K562 Leukemia Cells. Asian Pac. J. Cancer Prev. 2021, 22, $3959-3965$. [CrossRef]

50. Zhang, H.-F.; Wu, C.; Alshareef, A.; Gupta, N.; Zhao, Q.; Xu, X.-E.; Jiao, J.-W.; Li, E.-M.; Xu, L.-Y.; Lai, R. The PI3K/AKT/c-MYC axis promotes the acquisition of cancer stem-like features in esophageal squamous cell carcinoma. Stem. Cells 2016, 34, 2040-2051. [CrossRef]

51. Swords, R.-T.; Schenk, T.; Stengel, S.; Gil, V.-S.; Petrie, K.-R.; Perez, A.; Ana, R.; Watts, J.-M.; Vargas, F.; Elias, R. Inhibition of the $\mathrm{PI} 3 \mathrm{~K} / \mathrm{AKT} / \mathrm{mTOR}$ pathway leads to down-regulation of c-Myc and overcomes resistance to ATRA in acute myeloid leukemia. Blood 2015, 126, 1363. [CrossRef]

52. Chen, A.; Koehler, A.-N. Transcription factor inhibition: Lessons learned and emerging targets. Trends. Mol. Med. 2020, 26, 508-518. [CrossRef] [PubMed]

53. Zhu, W.-Q.; Wang, J.; Guo, X.-F.; Liu, Z.; Dong, W.-G. Thymoquinone inhibits proliferation in gastric cancer via the STAT3 pathway in vivo and in vitro. World J. Gastroenterol. 2016, 22, 4149. [CrossRef] 
54. Pang, J.; Shen, N.; Yan, F.; Zhao, N.; Dou, L.; Wu, L.-C.; Seiler, C.-L.; Yu, L.; Yang, K.; Bachanova, V. Thymoquinone exerts potent growth-suppressive activity on leukemia through DNA hypermethylation reversal in leukemia cells. Oncotarget 2017, 8, 34453. [CrossRef]

55. Braglia, L.; Zavatti, M.; Vinceti, A.; Martelli, A.-M.; Marmiroli, S. Deregulated PTEN/PI3K/AKT/mTOR signaling in prostate cancer: Still a potential druggable target? Biochim. Biophys. Acta Mol. Cell Res. 2020, 1867, 118731. [CrossRef]

56. Afrose, S.-S.; Junaid, M.-D.; Akter, Y.; Tania, M.; Zheng, M.; Khan, M.-D. Targeting kinases with thymoquinone: A molecular approach to cancer therapeutics. Drug. Discov. 2020, 25, 2294-2306. [CrossRef]

57. Krygier, A.; Szmajda-Krygier, D.; Sałagacka-Kubiak, A.; Jamroziak, K.; Żebrowska-Nawrocka, M.; Balcerczak, E. Association between the CEBPA and c-MYC genes expression levels and acute myeloid leukemia pathogenesis and development. Med. Oncol. 2020, 37, 109. [CrossRef] 